\title{
メカニカルアロイングを利用した FeAl-WCの作製
}

\author{
松本 章宏, 小林 慶三, 尾崎 公洋, 西尾 敏幸 \\ 産業技術総合研究所, 广 462-8510 名古屋市北区平手町 1-1.
}

\section{Fabrication of FeAl-WC Composite Using Mechanical Alloying}

\author{
Akihiro Matsumoto, Keizo Kobayashi, Kimihiro Ozaki and Toshiyuki Nishio \\ National Institute of Advanced Industrial Science and Technology, 1-1 Hirate-cho Kita-ku, Nagoya 462-8510.
}

Received July, 2001

\section{SYNOPSIS}

FeAl-WC composite was proposed as a potentially novel hard metal. FeAl powder was synthesized in a planetary ball mill under an argon atmosphere. Powder mixtures consisting of $\mathrm{FeAl}$ and $\mathrm{WC}$ powders were dry blended in an automatic agitator. FeAl-0 $65 \mathrm{vol} \% \mathrm{WC}$ composites were consolidated by pulse current sintering in a vacuum under the pressure application of $40 \mathrm{MPa}$. Vickers hardness of the obtained composites increased with increasing WC content and $1075 \mathrm{Hv}$ was obtained for FeAl-50vol\%WC composite. Transverse rupture strength of the composites was measured to be about $1.8 \mathrm{MPa}$ up to $30 \mathrm{vol} \% \mathrm{WC}$ and abruptly decreased to $1.1 \mathrm{GPa}$ for more than $50 \mathrm{vol} \% \mathrm{WC}$. Oxidation test at $1173 \mathrm{~K}$ exhibited weight gain of $\mathrm{FeAl}-50 \mathrm{vol} \% \mathrm{WC}$ was a one-seventh as much as that of Co$50 \mathrm{vol} \% \mathrm{WC}$.

\section{KEYWOROS}

iron aluminide, tungsten carbide, mechanical alloying, pulse current sintering, composite, vickers hardness, transverse rupture strength, oxidation resistance

\section{1 緒 需}

Coを結合相とする超硬合金は,WCとCoの濡れ性が優れて おり高強度の要因となっている。しかし，Coは希少金属であ るためコスト高になるとともに，耐酸化性に劣るためその使 用環境によっては材料劣化の原因となる，さらに，Coは PRTR法の第一種指定化学物質として指定されるなど,環境面 からその管理が厳しくなりつつある。

これまでに，Coに代わる結合相として， $\mathrm{Fe}^{1,2)}, \mathrm{Fe}-\mathrm{Ni}-\mathrm{C}$ 合金 ${ }^{3)}$ などを結合相とした合金に関する研究が報告されている、し かし，これらを結合相とした場合，耐酸化性の改善が期待で きないとともに，FeとWCの界面に脆化相が生成する問題が 残る.これに対して, 耐酸化性の改善などを期待して, $\mathrm{Ni}_{3} \mathrm{Al}^{4}$

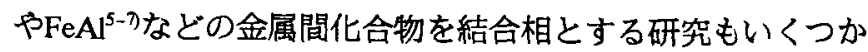
報告されている．このうち， FeAl はその構成元素が環境に優 しく，安価であるとともに，Alを多く含有しているため耐酸 化性にも優れている.さらに， FeAl は高硬度であるため，Co を結合相とする合金に比して少ない体積率で同じ硬度を達成 することができると考えられる。
本研究では, メカニカルアロイング(MA)法により合成した $\mathrm{Fe}-\mathrm{Al}$ 合金粉を結合相として FeAl-WC材を作製し，その機械 的特性や耐酸化性について調へ，新しい超硬合金としての可 能性を検討した。

\section{2 試料およひ実験方法}

$\mathrm{FeAl}$ 合金粉末の作製法には，MA法，燃焼合成法，アトマ イズ法などがある.このうち，燃焼合成法を用いると，10 $\mathrm{mm}$ 以下の微粉が得られるが,酸素量が約 0.8 mass\%と高くなると ともに，Fe が残存するなど $\mathrm{FeAl}$ 単相が得られにくい，また， アトマイズ法を用いると，高純度の合金粉末が得られるが， 粉末粒径が大きい(粒径 $100 \mu \mathrm{m}$ 以上が大部分を占める). 一 方，我々はこれまでにMA法を用いることによって，10 $\mu \mathrm{m}$ 程 度の粉末粒径を有し, 酸素量も約 0.3 mass\%程度と良質な $\mathrm{FeAl}$ 粉末か作製可能であることを報告しているす.そこで本研究で は FeAl 合金粉末の作製手法として MA 法を採用した。

市販の Fe粉 (99.85 mass\%)，Al粉 (99.9 mass\%)を Fe-40at\%Al 組成となるように粉末量 $30 \mathrm{~g}$ を秤量し，遊星型ボールミルに 
て公転速度 $170 \mathrm{rpm}, 66 \mathrm{kPa}$ の $\mathrm{Ar}$ 雾囲気中で $360 \mathrm{ks}$ のミリング を行った．用いたポットは内容積 $500 \mathrm{ml}$ のステンレス鋼製， ボールは $10 \phi \mathrm{mm}$ のクロム鋼製である.また, ボールの総重量 を $400 \mathrm{~g}$, 粉末/ボールの重量比 $=1 / 13$ とした. 得られたミリ ング粉に市販のWC粉 $(0.65 \mu \mathrm{m})$ を FeAl-0〜 65vol\%WCとなる ように配合し, 自動乳鉢(メ)ウ製の乳鉢および乳棒)にて $1.8 \mathrm{ks}$ 乾式混合を行った. 続いて混合粉を黒鉛型に充填し，パルス 通電焼結法にて $5 \times 9 \times 30 \mathrm{~mm}^{3}$ の直方体形状の試料を作製した. ここで, FeAl-WC混合粉の焼結法としては, 真空下での無加 圧焼結あるいは加圧焼結が考えられる. 真空無加圧焼結を用 いたところ, $20 \mu \mathrm{m}$ 程度の空孔が多数残存した焼結体が得ら れ，緻密化は達成できなかった。したがって，真空加圧下で， しかも短時間での焼結ができ量産化が見込めるパルス通電焼 結法を用いて焼結を行うこととした. 得られた焼結体の表面 を平面研削することにより $4 \times 8 \times 28 \mathrm{~mm}^{3}$ の試験片とし, 室温 にて標点間距離 $20 \mathrm{~mm}$ で抗折試験を行った．また，荷重 $5 \mathrm{~kg}$ を負荷してビッカース硬度試験を，光学顕微鏡および EPMA により組織観察を,X線回折により構成相の同定を行った.さ らに，TGAを用いて大気中 $1173 \mathrm{~K} て ゙ ~ 7.2 \mathrm{ks}$ 保持することによ り酸化増量試験を行った。

\section{3 奏験結果および考察}

Fig.1 に純 Fe 粉および純 $\mathrm{Al}$ 粉を出発原料として $360 \mathrm{ks} の ミ$ リングにより合成された Fe-40at\%Al粉およびWC粉のSEM像 を示す. $\mathrm{Fe}-40 \mathrm{at} \% \mathrm{Al}$ ミリング粉の粒径は $20 \mu \mathrm{m}$ 以下，WCは サブミクロンの微粉である. Fe-40at\%Al ミリング粉のX線回 折の結果, $2 \theta=43.8,63.5,80.5$ (deg.) 付近の 3 本の明瞭な回折

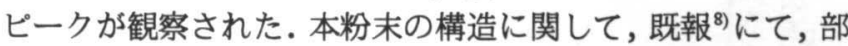
分的に $\mathrm{B} 2$ 構造を有してはいるものの $\mathrm{Fe}$ サイトと $\mathrm{Al}$ サイトが ランダムに置換している, いわゆる B2 構造への遷移過程の準 安定状態であるとする解釈が適当であると結論づけた。

$\mathrm{Fe}-40 \mathrm{at} \% \mathrm{Al}$ ミリング粉に WC 粉を FeAl-0〜 65vol\%WCとな るように配合し，自動乳鉢にて $1.8 \mathrm{ks}$ 乾式混合後, パルス通電 焼結法にて 1373〜1473 K×300s なる条件で焼結した. Fig.2に FeAl-WC 材の X 線回折の結果を示す.いずれの試料もほぼ
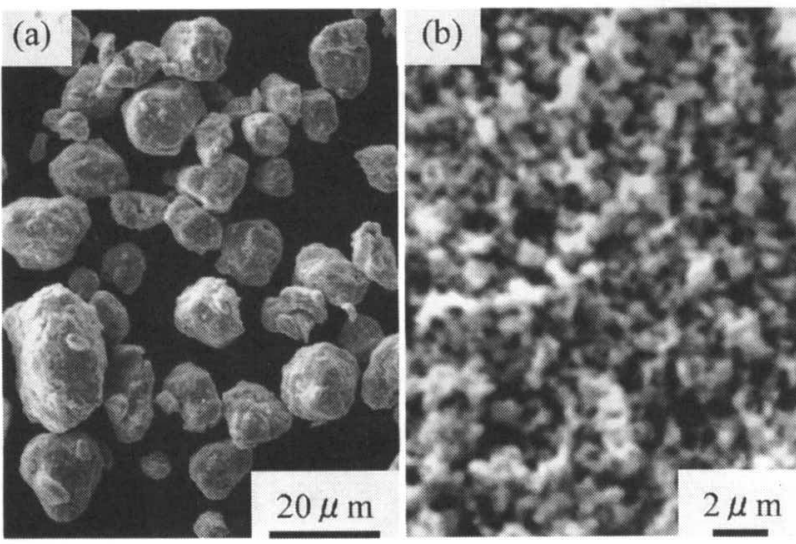

Fig.1 SEM images of (a) $\mathrm{Fe}-40 \mathrm{at} \% \mathrm{Al}$ powder milled for $360 \mathrm{ks}$ and (b) WC powder.
$\mathrm{FeAl}$ とWCの二つの相で構成されているがわかる.すなわち， ミリングした Fe-40at\%Al粒子の構造は, 焼結により安定相で ある金属間化合物 $\mathrm{FeAl}$ に変化したことを示している.

Fig.3に光学顕微鏡により観察した組織を示す. 白地の部分 が $\mathrm{FeAl}$ を示しており, その形状は MA粉の断面を反映した円 形形状となっている. そして, その周囲をサブミクロンのWC 粒子が埋めている. WC 粒子は出発原料の WC 粉末の粒径を 保持しており, 今回の焼結条件では粒子の粗大化は観察され なかった. また, FeAl 粒子の外径は WC 量が増すほど小さく なっている.これは WC 量が多い試料ほど焼結温度を高く設 定しているため, MA粒子がより軟化して，WC粒子の間隙に 浸透しやすくなったためと考えられる.SEMを用いて組織観 察を行ったところ, $\mathrm{FeAl}$ と WCの界面での反応生成物は観察 されなかった. ただし, 65vol\%WC材については, Fig.3から もわかるように，円形の FeAl の周囲に粒状の相が観察され た. $65 \mathrm{vol} \%$ 材については, PCS 法のみでは緻密化が困難で あったため, $200 \mathrm{MPa}$ の圧力で $1573 \mathrm{~K} \times 7.2 \mathrm{ks}$ の HIP処理を行っ た.これにより, 何らかの化合物が生成した可能性があるため, 今後詳細に調べる必要がある. なお, 得られた FeAl-0〜 65vol\% WC 材の相対密度は, Ovol\%WC材の 99.7\% から 50vol\%WC材 の 97.0\% まで順次低下したものの, よく緻密化していると思 われる. なお, $65 \mathrm{vol} \% \mathrm{WC}$ 材は HIP 処理を行ったため, その 相対密度は $98.3 \%$ と測定された。

Fig.4にFeAl-WC複合材の抗折力とビッカース硬度のWC量 依存性を示す，ビッカース硬度の值は，0vol\%WC材の 420 か

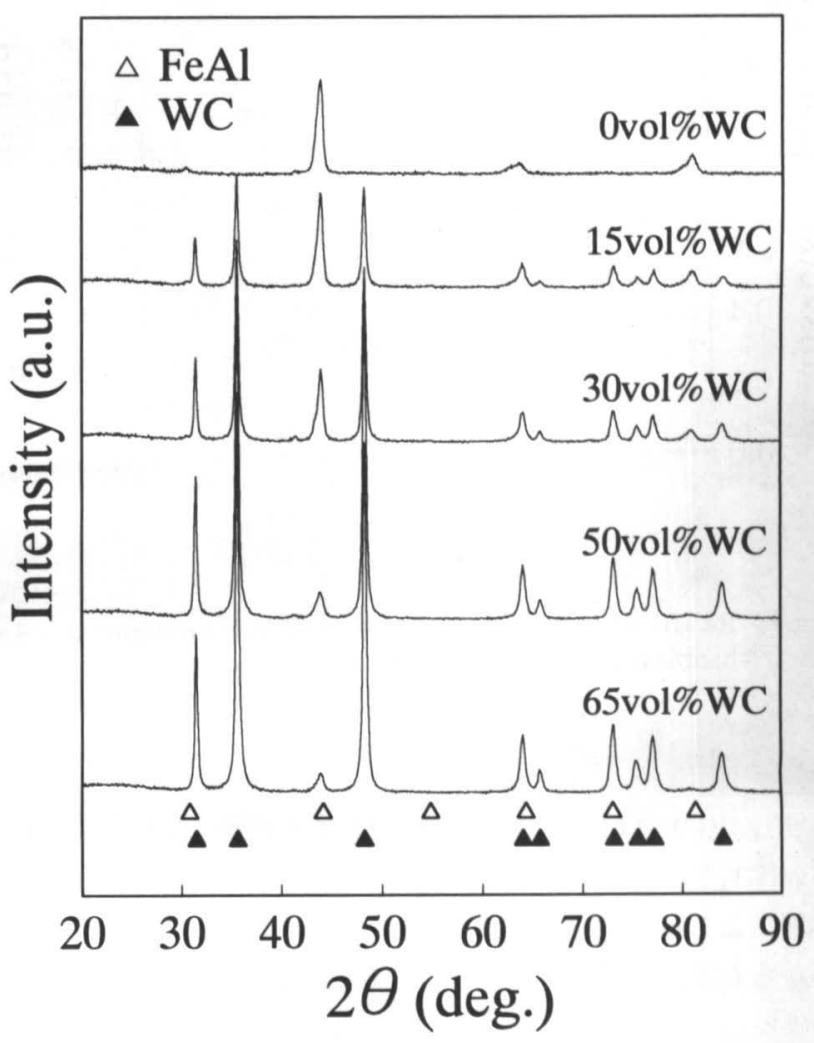

Fig.2 X-ray diffraction patterns of FeAl-WC composites. 


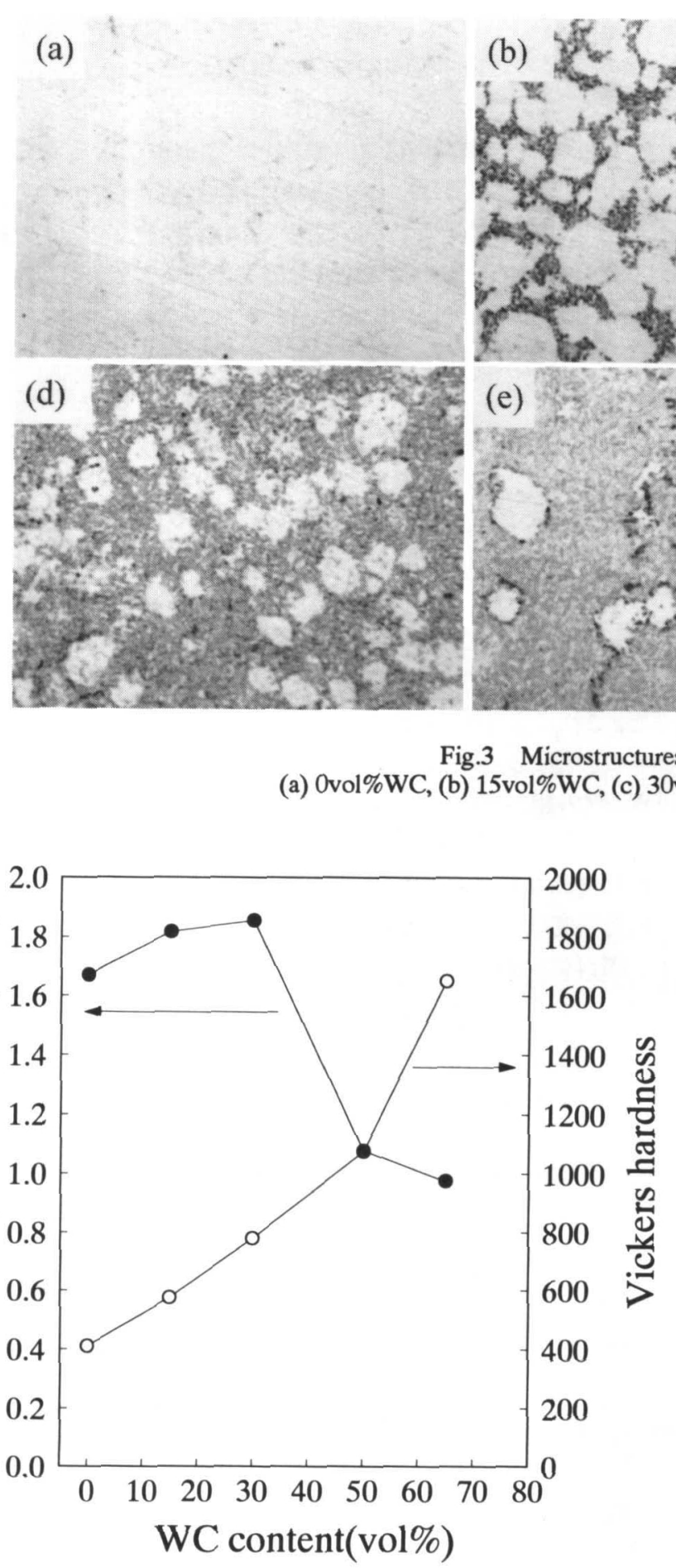

Fig.4 Relationship between transverse rupture strength, Vickers hardness and WC content for $\mathrm{FeAl}$-composites.

ら 50vol\%WC 材の 1075 まではほぼ直線的に増加するが， $65 \mathrm{vol} \% \mathrm{WC}$ 材では 1700 となり，急激に増加する．これはHIP 処理による䋴密化に起因するものと思われるが，先の組織観 察からも反応生成物らしきものが観察されるため,これによ る硬度の上昇の可能性もある。一方, 抗折力は $0 \sim 30 \mathrm{vol} \% \mathrm{WC}$ 材では約 $1.8 \mathrm{GPa}$ を示すが,これよりも高いWC含有量では約

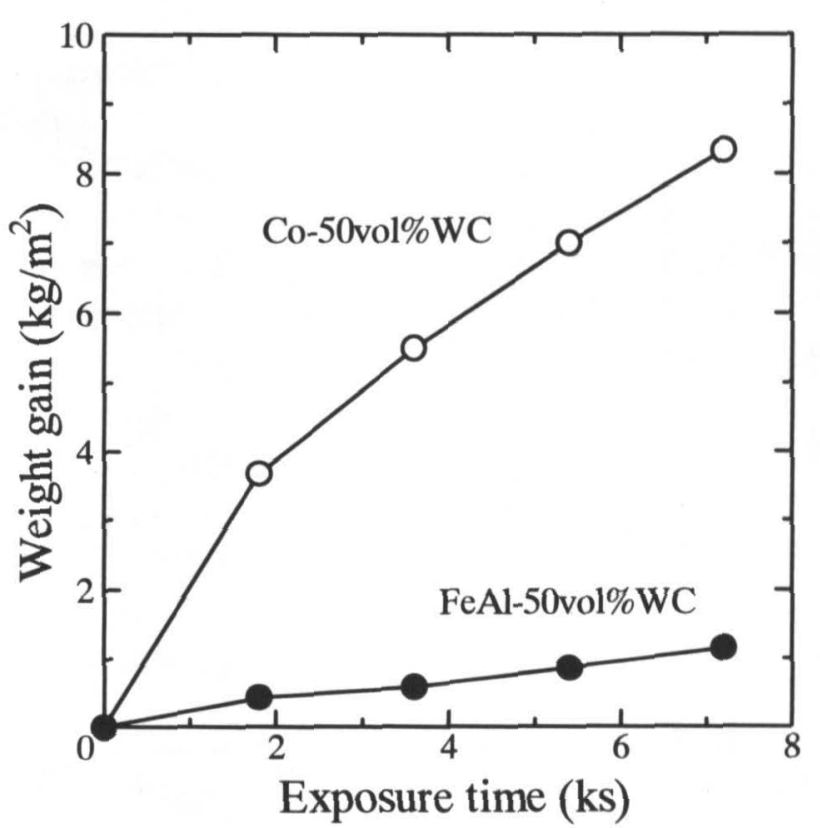

Fig.5 Relationship between weight gain and exposure time for FeAl-50vol\%WC composite.

$1.1 \mathrm{GPa}$ に急激に低下する.これは Fig.3 からわかるように， $\mathrm{FeAl}$ 粉とWC粉の粒径差が大きいため, 結合相である FeAlが 十分に WC 粒子の間隙に浸透することができず, WC粒が㠜 集した部分でクラックが発生しやすいことに起因すると思わ れる.

Fig.5に FeAl-50vol\%WC材の TGA を用いた酸化試験の結果 を示す. 条件としては, 大気中で $1173 \mathrm{~K} \times 7.2 \mathrm{ks}$ 保持とし, 比 
較材としてCo-50vol\%WC材も同様に試験を行った．切削工 具として使用される超硬合金は,被削材によっては刃先が873 〜 $1273 \mathrm{~K}$ に達するとされる. 特に，最近，環境問題から切削 油を用いない機械加工が要望されており，この場合，切削工 具の刃先はさらに高温となることが予想される. Fig.5から， $7.2 \mathrm{ks}$ 試験後の FeAl-50vol\%WC材の重量増加はCo-50vol\%WC 材の約 1/7であり，Coを結合相とした超硬合金より明らかに 耐酸化性に優れていることがわかる。これは，FeAl は構成元 素として $\mathrm{Al}$ を多く含んでいるため，その表面に安定な $\mathrm{Al}_{2} \mathrm{O}_{3}$ 膜を形成することに起因している．このことから，FeAl-WC 材は切削油フリーの機械加工に対応した切削工具としての可 能性を有していると考えられる.

さて，FeAlを結合相として硬質材料を作製しようとする試 みがいくつか報告されている. 小林ら ${ }^{5}$ はWC $(0.5 \mu \mathrm{m}), \mathrm{Fe}, \mathrm{Al}$ 素粉末をアトライタにて湿式湿合後, 真空および HIP 処理 $(1713 \mathrm{~K} \times 2.4 \mathrm{ks})$ することにより, WC-6.7mass\%Fe-3.3mass\%Al 超硬合金( 結合相は Fe-50at\%Al 組成，WC-19vol\%FeAl 相当) を 作製し, 抗折力約 $1.2 \mathrm{GPa}$, ロックウェル硬度 $91.7 \mathrm{HRA}$ (ビッカー 不硬度約 1820 相当)肪得られたと報告している.ただし，十 分な緻密化は達成しておらず，耐酸化性に至ってはCoを結合 相とした超硬合金に比して劣るという結果を得ている.また， R. Subramanian らのは melt infiltration 法を用いて FeAl-WC複合 材 (WC 粒径 : $2.8 \mu \mathrm{m}$ ) を作製したところ，WC-30vol\% FeAl 材 で抗折力 $1.4 \mathrm{GPa}$ ，ロックウェル硬度 88HRA (ビッカース硬度 約 1245 相当) が得られ，さらに $1173 \mathrm{~K}$ での酸化增量もCoを 結合相としたものの約 1/5であったと報告している.

まず，作製手法に関して，小林らの HIP 処理や R. Subramanian らの melt infilteration 法に比して, 本研究で用いたパルス通電 焼結は，より量産化が見込める手法であり，優位性があると 思われる. 次に耐酸化性に関して，本研究で得られた FeAl-

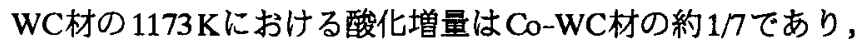
小林らやR. Subramanian らにより得られた值に比して良好な 值が得られた。最後に，機械的特性に関して，本研究で作製し た FeAl-WC材の硬度，抗折力は50vol\%WC材でそれぞれ 1075, $1.1 \mathrm{GPa}$ が得られたものの, 先に述べた小林らやR. Subramanian らにより得られた值に比して低い值となった.WC粒径やWC 体積率が異なるため一概に比較できないが，組織の不均質性 に大きな要因あると思われる．したがって，今後 $\mathrm{FeAl}$ 粒子の 微粒化を図り，不均質性を改善することによって，機械的特 性の向上が期待できると考えられる。

\section{4 ま と め}

メカニカルアロイング(MA)法により合成した Fe-Al合金粉 を結合相として, パルス通電焼結法により FeAl-WC材を作製 し，その機械的特性や耐酸化性について調べた結果，以下の
ことが明らかとなった。

(1) MA-パルス通電焼結プロセスにより相対密度 $97 \%$ (50vol\% WC 材) 以上の緻密な FeAl-WC 材を作製できた。また， FeAl とWCの界面に反応生成物は観察されなかった。

(2) FeAl-WC材の硬度はWC量に比例して增加し，50vol\%WC 材でビッカース硬度 $1075 \mathrm{Hv}$ が得られた。

(3) FeAl-WC材の抗折力は, 30vol\%WCまでは約 $1.8 \mathrm{GPa}$ が得 られたが，さらにWCの増加により急激に低下し，50vol\% WCで約 $1.1 \mathrm{GPa}$ となった.この抗折力の低下は組織の不 均質性に起因していると考えられる。

(4) $1173 \mathrm{~K}$ における FeAl-50vol\%WC材の酸化增量は，Co50vol\%WC材の約 $1 / 7$ であり，耐酸化性に優れていること が示された.

\section{謝辞}

抗折試験を行うにあたり多大なるご協力をいただきました 滋賀県東北部工業技術センターの所敏夫主査に深く感謝いた します。

\section{文献}

1) 宮崎邦彰, 伊藤茂, 小浦延幸, 米田登, 浅香一夫: "HIP 法 による Fe-WC 系複合材料の作製 ", 粉体および粉末治金， 37(1990)219-224.

2) A.Trueman, D.P.Schweinsberg and G.A.Hope: "The matrix corrosion of tungsten carbide/carbon steel metal matrix composites", Corrosion Science, 39(1997)1153-1164.

3) T.Kakeshita and C.M.Wayman: "Martensitic transformation in cermets with a metastable austenitic binder I: WC- $(\mathrm{Fe}-\mathrm{Ni}-\mathrm{C})$ : Materials Science and Engineering, A141(1991)209-219.

4) T.N.Tiegs, K.B.Alexander, K.P.Plucknett, P.A.Menchhofer, P.F.Becher and S.B.Waters: Materials Science and Engineering, A209(1996)243-247.

5) 小林憲三,三輪謙治, 福永稔, 町田正弘: " $\mathrm{Fe}-\mathrm{Al}$ 合金を結 合相にした超硬合金の作製 ", 粉体および粉末冶金, 41 (1994)14-17.

6) R.Subramanian and J.H.Schneibel: "Processing Iron-Aluminide Composites Containing Carbides or Borides", JOM, (1997)5054.

7) R.Subramanian and J.H.Schneibel: "FeAl-TiC and FeAl-WC composites-melt infiltration processing, microstructure and mechanical properties, Materials Science and Engineering, A244 (1998)103-112.

8）松本章宏, 小林慶三, 西尾敏幸, 尾崎公洋, 杉山明: "MAパルス通電焼結により作製した FeAl の組織と機械的特性", 粉体および粉末治金, 47(2000)1253-1257. 